\title{
Effects of essential oil combinations on sheep ruminal fermentation and digestibility of a diet with fumarate included
}

\author{
B. Lin ${ }^{\mathrm{a}, \mathrm{b}}$, Y. Lu $^{\mathrm{a}}$, A.Z.M. Salem ${ }^{\mathrm{c}, \mathrm{d}}$, J.H. Wang ${ }^{\mathrm{a}}$, Q. Liang ${ }^{\mathrm{a}}$, J.X. Liu ${ }^{\mathrm{a}, *}$ \\ a Institute of Dairy Science, Ministry of Education Key Laboratory of Molecular Animal Nutrition, College of Animal Sciences, Zhejiang \\ University, Hangzhou 310029, China \\ b Guangxi Buffalo Research Institute, Chinese Academy of Agricultural Sciences, Nanning 530001, China \\ c Facultad de Medicina Veterinaria y Zootecnia, Universidad Autónoma del Estado de México, Estado de México, Mexico \\ d Faculty of Agriculture (El-Shatby), Alexandria University, Egypt
}

\section{A R T I C L E I N F O}

\section{Article history:}

Received 17 July 2012

Received in revised form 11 May 2013

Accepted 13 May 2013

\section{Keywords:}

Digestibility

Essential oil

Rumen fermentation

Sheep

\begin{abstract}
A B S T R A C T
Four Hu sheep $(27.5 \pm 2.6 \mathrm{~kg}$ body weight $)$, fitted with ruminal and duodenal fistula, were used to investigate the effects of a mixture of essential oils (EO) or their active components on rumen fermentation, microbial population, and nutrient digestibility. Four treatments in $4 \times 4$ Latin square design were used: basal diet added with $25 \mathrm{~g} /$ day monosodium fumarate (Control); Control plus $1 \mathrm{~g} /$ day of EO combinations (EOC, mixture of equal ratio of oil from clove, oregano, cinnamon, and lemon); and Control plus 0.5 or $1.0 \mathrm{~g} /$ day EO active component combinations (EOAC, mixture of eugenol, carvacrol, citral and cinnamaldehyde in equal ratio). The EOC and EOAC treatments were absorbed into microporous starch, and the complex was encapsulated with sodium alginate before use. Each treatment period lasted for 21 days, including 12 days for adaptation. Rumen samples were taken to determine volatile fatty acid (VFA) content and microbial flora. Microbial populations were measured using real-time PCR. The apparent digestibility of nutrients in the total tracts or at different tract parts was measured through total collection method or indicator method, respectively. Rumen pH did not change with the addition of EOC or EOAC. Ammonia nitrogen concentration decreased after addition of either EOC or EOAC. Total VFA content decreased with the addition of EOC or high level of EOAC, with little change under low dose of EOAC. Propionate increased $(\mathrm{P}<0.05)$ in animals treated with EOAC or $0.5 \mathrm{~g}$ EOAC compared with the control. The ratio of acetate to propionate decreased $(\mathrm{P}<0.05)$ with the addition of EOC or EOAC. Protozoan population decreased $(\mathrm{P}<0.05)$ with the addition EOC and EOAC, with lower population in the EOAC-treated animals than in the EOC-treated group. The growth of methanogens, Fibrobacter succinogenes, and Butyrivibrio fibrisolvens $(\mathrm{P}<0.05)$ was inhibited by addition of EOAC, but not by EOC. Population of fungi and Ruminococcus flavefaciens did not change with the addition of EOC or EOAC. Addition of EOC and EOAC did not influence the feed intake and digestibility of the nutrients in total or at different parts of the digestive tract, but decreased ruminal protein digestibility. Addition of EOC and EOAC
\end{abstract}

\footnotetext{
Abbreviations: ADFom, acid detergent fiber exclusive residual ash; CP, crude protein; DM, dry matter; DMI, DM intake; EO, essential oils; EOC, essential oils combination; EOAC, essential oils active compounds combination; NDFom, neutral detergent fiber exclusive residual ash; OM, organic matter.

* Corresponding author at: Institute of Dairy Science, Ministry of Education Key Laboratory of Molecular Animal Nutrition, College of Animal Sciences, Zhejiang University, Hangzhou, China. Tel.: +8657188982097.

E-mail address: liujx@zju.edu.cn (J.X. Liu).
} 
has no obvious harmful effects on rumen fermentation in terms of ruminal dry matter and fiber digestibility was not influenced. The proportion of ruminal propionate increased, and protein degradation was inhibited. In this study, the addition of $1 \mathrm{~g} /$ day EOC or EOAC had no detrimental effects on sheep nutrient digestion.

Crown Copyright @ 2013 Published by Elsevier B.V. All rights reserved.

\section{Introduction}

Plant essential oils (EO) are volatile and lipophilic compound mixtures extracted from plants through distillation (Benchaar et al., 2008; Westendarp, 2005). In recent years, EO have been used as a potential alternative in manipulating rumen fermentation (Busquet et al., 2006; Castillejos et al., 2006). Numerous results show that EO have bioactivities, such as selective anti-bacterial activity, inhibition of ruminal methane emission, as well as enhancement of ruminal propionate proportion and bypass protein to the intestine (Wallace, 2004; Macheboeuf et al., 2008). Chemically, EO are variable mixtures comprising a variety of compounds with low molecular weight, such as aliphatic hydrocarbons, acids, alcohols, aldehydes, phenols, acyclic esters or lactones, and others (Bakkali et al., 2008).

Each type of EO has one or several main compounds that determine its key bioactivities. A number of in vitro experiments also report that the main components of EO show similar effects on ruminal fermentation as their corresponding natural EO (Macheboeuf et al., 2008; Castillejos et al., 2006). The effects of EO on ruminal fermentation vary with their main components (Busquet et al., 2006; Macheboeuf et al., 2008). Thus, combining different types of EO or EO components together can produce many new types of EO (Bakkali et al., 2008), and the effective methane inhibitor may be identified from these new EO. Furthermore, if combining different EO components together can replace natural EOs as additive, existing problems on natural EO such as composition instability, difficulties in collection, and high cost, can be solved. Previous in vitro experiments found that a balanced combination of EO and EO active components (a mixture of thyme, oregano, cinnamon, and lemon essential oil at an equal ratio, and a mixture of eugenol, carvacrol, citral, and cinnamylaldehyde at an equal ratio) has greater methane reduction ability compared with other combinations (Lin et al., 2012, 2013).

Fumarate is an electron acceptor in the rumen that can be used as a hydrogen competitor for methanogens to inhibit methane production (Asanuma et al., 1999; Ungerfeld et al., 2007). Many in vitro studies reported that the addition of fumarate coupled with methane inhibitor can lead to a synergistic effect that can inhibit ruminal methane production (Abdl-Rahman et al., 2010; Baraka and Abdl-Rahman, 2012). Addition of fumarate coupled with EO or EO active components decreases methane and ammonia production, compared with addition of only EO active components (Lin et al., 2012). Information on the effects of the addition of EO or their active compounds coupled with fumarate on nutrient digestibility in vivo is limited. In vivo studies are important to confirm the effectiveness and applicability of methane inhibitors screened from in vitro experiments. To date, most in vivo studies on EO are mainly concerned with effects on ruminal fermentation or nutrient apparent digestibility; intestinal digestibility is usually overlooked.

The present study is conducted based on two of our previous in vitro studies (Lin et al., 2012, 2013), whereby optimal methane-inhibiting combinations of EO or EO components with fumarate were screened. This work aims to confirm prior in vitro experiment results in in vivo conditions. Experiments are designed to investigate the effects on ruminal fermentation and microbial population, as well as ruminal, intestinal, and nutrient apparent digestibility of the mixture of EO or their active components with fumarate addition to sheep feed. As the high volatility and strong smell of EO would reduce feed palatability and animal feed intake (Cardozo et al., 2006; Calsamiglia et al., 2007), this study adopts the microencapsulation embedding technology to treat EO before use.

\section{Materials and methods}

\subsection{Animals, feeding, and experimental design}

This experiment was conducted in accordance to the Zhejiang University Guidelines for the Care and Use of Experimental Animals. Four Hu sheep, with an initial body weight of $25 \pm 1.5 \mathrm{~kg}$, fitted with ruminal, duodenal, and ileal fistulas, were used in a $4 \times 4$ Latin square design involving four treatments: basal diet added with $25 \mathrm{~g} /$ day of monosodium fumarate (diet C); diet C plus $1 \mathrm{~g} /$ day of EO combination (diet EOC, EOC is a mixture composed of oil from clove, oregano, cinnamon, and lemon in an equal ratio); diet C plus $0.5 \mathrm{~g} /$ day of EO active components combination (diet LEOAC), and diet C plus $1.0 \mathrm{~g} / \mathrm{day}$ of EO active components combination (diet HEOAC). EOAC is a mixture of eugenol, carvacrol, citral, and cinnamaldehyde in an equal ratio. Before the addition of additives to the animal diets, the EOC and EOAC were absorbed by microporous starch (Wang et al., 2009), and the complex was encapsulated with sodium alginate according to the method of Chan et al. (2000), with some modifications.

Sheep were fed daily with a $900 \mathrm{~g} /$ day maintenance diet, including $500 \mathrm{~g}$ of Chinese wild rye (Aneurolepidium chinense), hay (air dry basis), and $400 \mathrm{~g}$ of concentrate mixture (air dry basis). The ingredients and nutritional composition of the basal diet are shown in Table 1. The fumarate and encapsulated EOC or EOAC were added into the concentrate. Sheep were fed twice daily in two equal portions at 08:30 and 17:00, and had free access to water. They were kept individually in stainless 
Table 1

Ingredient and nutrient composition $(\mathrm{g} / \mathrm{kg})$ of the basal diet fed to the sheep.

\begin{tabular}{|c|c|}
\hline Item & Amount \\
\hline \multicolumn{2}{|l|}{ Ingredient } \\
\hline Chinese wild rye & 555 \\
\hline Ground corn & 267 \\
\hline Soybean meal & 89 \\
\hline Wheat bran & 71 \\
\hline Salt & 7 \\
\hline $\mathrm{Ca}_{2} \mathrm{HPO}_{4}$ & 10 \\
\hline Premix $^{a}$ & 1 \\
\hline \multicolumn{2}{|l|}{ Nutrient composition } \\
\hline Dry matter & 868 \\
\hline Organic matter & 946 \\
\hline Crude protein & 97 \\
\hline Neutral detergent fiber & 422 \\
\hline Acid detergent fiber & 248 \\
\hline $\mathrm{Ca}$ & 6.3 \\
\hline $\mathrm{P}$ & 3.9 \\
\hline
\end{tabular}

a Premix contained per kilogram: $119 \mathrm{~g} \mathrm{MgSO}_{4} \cdot \mathrm{H}_{2} \mathrm{O}, 2.5 \mathrm{~g} \mathrm{FeSO}_{4} \cdot 7 \mathrm{H}_{2} \mathrm{O}, 0.8 \mathrm{~g} \mathrm{CuSO}_{4} \cdot 5 \mathrm{H}_{2} \mathrm{O}, 3 \mathrm{~g} \mathrm{MnSO}_{4} \cdot \mathrm{H}_{2} \mathrm{O}, 5 \mathrm{~g} \mathrm{ZnSO} 4 \cdot \mathrm{H}_{2} \mathrm{O}, 10 \mathrm{mg} \mathrm{Na}_{2} \mathrm{SeO}_{3}, 40 \mathrm{mg} \mathrm{KI}, 30 \mathrm{mg}$ $\mathrm{CoCl}_{2} \cdot 6 \mathrm{H}_{2} \mathrm{O}, 95,000 \mathrm{IU}$ vitamin $\mathrm{A}, 17,500 \mathrm{IU}$ vitamin $\mathrm{D}$, and 18,000 IU vitamin $\mathrm{E}$.

steel metabolism cages in a temperature-controlled $\left(20^{\circ} \mathrm{C}\right)$ and constantly lit house. Each experimental period lasted for 21 days, of which the first 12 days were for adaptation, and the remaining 9 days were for sampling.

\subsection{Digestion trial}

\subsubsection{Sampling schedule}

Diets and orts offered were recorded daily. Samples of duodenal and ileal digesta were taken daily and composited per sheep during the sampling period. Samples were dried at $65^{\circ} \mathrm{C}$ for $48 \mathrm{~h}$ for subsequent analysis of chemical compositions to calculate feed intake and digestion. Samples of feces from each animal were collected daily from day 16 to day 20 with the aid of collection bags tied to the rear of the sheep. Accumulated feces were removed and weighed daily for 5 days, and $10 \%$ of the representative samples were collected and stored at $-20^{\circ} \mathrm{C}$ for chemical analysis.

Nutrient apparent digestibility at different sites of the digestive tracts was measured through the indicator method. Duodenal and ileal digesta flows were determined using chromium oxide $\left(\mathrm{Cr}_{2} \mathrm{O}_{3}\right)$ as a marker, according to previously described procedures (Tan et al., 2001). One gram of $\mathrm{Cr}_{2} \mathrm{O}_{3}$ was administered through the rumen cannula at 06:00, 12:00, 18:00, and 24:00 h (a total of $4 \mathrm{~g} \mathrm{Cr}_{2} \mathrm{O}_{3}$ /day) from day 13 to day 20, with a priming dose of $2 \mathrm{~g}$ at 06:00 h on day 13 (a total of $5 \mathrm{~g}$ of $\mathrm{Cr}_{2} \mathrm{O}_{3}$ /day). Approximately, $30 \mathrm{ml}$ of duodenal and ileal contents were collected at 09:00, 15:00, 21:00, and 03:00 on day 18, at 07:00,13:00, 19:00, and 01:00 on day 19, and at 05:00,11:00, 17:00, and 23:00 on day 20. This schedule provided a total of 12 representative samples of duodenal and ileal contents taken at $2 \mathrm{~h}$ intervals. Samples were sub-sampled after the sampling period, mixed across sampling times for each sheep and each period, dried at $65^{\circ} \mathrm{C}$, ground to pass a $1 \mathrm{~mm}$ sieve, and then stored for chemical analysis.

\subsubsection{Analyses of chemical composition}

Samples of feed orts were ground through a $2 \mathrm{~mm}$ screen using a Wiley mill (Arthur $\mathrm{H}$. Thomas, Philadelphia, PA), whereas samples of digesta and feces were ground through a $1 \mathrm{~mm}$ screen using a Cyclotec mill (Tecator 1093, Hoganas, Sweden). Dry matter (DM) and organic matter (OM) contents were determined according to No. 942.05 (AOAC, 1997), and crude protein (CP) was analyzed according to No. 988.05 (AOAC, 1997). Neutral detergent fiber (NDFom) and acid detergent fiber (ADFom) were analyzed using a fiber analyzer (FIWE6, VELP, Italy) according to Van Soest et al. (1991). To measure the NDFom, $1 \mathrm{~g}$ of ground sample plus $0.5 \mathrm{~g}$ of sodium sulfite and $50 \mu 1$ of heat-stable amylase (A 3306, Sigma, USA) were added to 100 ml of neutral detergent solution; the mixture was boiled and refluxed for $60 \mathrm{~min}$. Filtered residues were washed with boiling water and then ashed in a muffle at $550^{\circ} \mathrm{C}$ for $3 \mathrm{~h}$. The ADFom was measured using the same procedure except that the neutral detergent solution was replaced by acid detergent solution, and sodium sulfite and heat-stable amylase were eliminated.

\subsubsection{Calculation of nutrient digestibility}

Total nutrient apparent digestibility was calculated according to the difference between nutrient intake and fecal output. The duodenal and ileal flows, as well as the apparent digestibility of nutrients, were calculated according to Tan et al. (2001), with modifications. 
Table 2

Ruminal microbe primers for qPCR assay.

\begin{tabular}{lll}
\hline Target species & Forward/reverse & Primer sequence \\
\hline Total bacteria & $\mathrm{F}$ & CGGCAACGAGCGCAACCC \\
Methanogens & $\mathrm{R}$ & CCATTGTAGCACGTGTGTAGCC \\
& $\mathrm{F}$ & TTCGGTGGATCDCARAGRG \\
Total fungi & $\mathrm{R}$ & GBARGTCGWAWCCGTAGAATCC \\
& $\mathrm{F}$ & GAGGAAGTAAAAGTCGTAACAAGGTTTC \\
Protozoa & $\mathrm{R}$ & CAAATTCACAAAGGGTAGGATGATT \\
& $\mathrm{F}$ & GCTTCGWTGGTAGTGTATT \\
F. succinogenes & $\mathrm{R}$ & CTTGCCCTCYAATCGTWCT \\
& $\mathrm{F}$ & GTTCGGAATTACTGGGCGTAAA \\
R. flavefaciens & $\mathrm{R}$ & CGCCTGCCCCTGAACTATC \\
& $\mathrm{F}$ & CGAACGGAGATAATTGAGTTACTTAGG \\
\hline
\end{tabular}

The primers were designed by Denman and McSweeney (2006) and Denman et al. (2007).

\subsection{Ruminal fermentation parameters}

On day 21 of each period, ruminal fluid samples $(50 \mathrm{ml})$ were collected via the ruminal cannula at $0,3,6$, and $9 \mathrm{~h}$ after morning feeding. Samples were squeezed through four layers of cheesecloth with a mesh size of $250 \mu \mathrm{m}$ for analysis of pH, ammonia nitrogen, and volatile fatty acids (VFA). One part of the sample at $0 \mathrm{~h}$ was reserved at $-80^{\circ} \mathrm{C}$ for analysis of microbial population through real time polymerase chain reaction (RT-PCR). The $\mathrm{pH}$ was determined immediately using a pH meter (model PB-10/C, Sartorius, Goettingen, Germany). Concentration of ammonia nitrogen was determined colorimetrically through a phenol-hypochlorite method according to Searle (1984). VFA content was determined using a gas chromatograph (GC-2010, Shimadzu, Kyoto, Japan) equipped with a Flame Ionization Detector and a capillary column (HP-INNOWAX, 1909N133, Agilent Technologies, Santa Clara, CA, USA), as described previously (Hu et al., 2005).

\subsection{Rumen microbial population}

The frozen samples were thawed at room temperature, and total DNA was extracted through bead-beating using the minibead beater (Biospec Products, Bartlesville, OK, USA), as described by Zhang et al. (2008). RT-PCR assays for microorganisms were conducted as reported (Lin et al., 2012). The PCR mixture consisted of $2 \mu$ l template DNA, $2 \mu l 10 \times$ buffer, $0.2 \mathrm{mM}$ dNTP, 25 pmol primer (reverse), 25 pmol primer (forward), $1.5 \mathrm{mM} \mathrm{MgCl}_{2}$, and $0.2 \mu \mathrm{l} \mathrm{Taq}$, all in a total volume of $20 \mu \mathrm{l}$. PCR was completed as follows: one cycle at $95^{\circ} \mathrm{C}$ for $10 \mathrm{~s}$ as initial denaturation, followed by 40 cycles of denaturation at $95^{\circ} \mathrm{C}$ for $5 \mathrm{~s}$ and annealing at $60^{\circ} \mathrm{C}$ for $34 \mathrm{~s}$. The primers were designed according to Denman and McSweeney (2006) and Denman et al. (2007) (Table 2). Quantitative PCR was performed with a 7500 RT-PCR System (Applied Biosystems, Foster City, CA, USA) using SYBR Premix Ex Taq II Perfect Real Time (TaKaRa Bio Inc., Otsu, Shiga, Japan).

\subsection{Data calculation and statistical analysis}

The population abundance of ruminal methanogenesis and fiber digestion by highly-related microbes, methanogens, protozoa, fungi, Ruminococcus albus, Ruminococcus flavefaciens, and Fibrobacter succinogenes were calculated from the RTPCR results. Relative abundance was expressed as a proportion of the number of specific gene fragments to the number of total rumen bacterial 16S rDNA, which was calculated according to the following equation: relative quantification (\% of total bacterial 16S rDNA $)=2^{-\Delta \Delta C t}=2^{-(\Delta C t \text { target }-\Delta C \text { total bacteria })}$, where $\mathrm{Ct}$ represents threshold cycle.

The data were analyzed as a $4 \times 4$ Latin square design using the global linear models procedure of the SAS software (SAS Institute, 2005). The model used was as follows: $Y_{i j k l}=\mu_{i}+G_{i}+P_{j}+T_{k}+e_{i j k l}$, where $\mu$ is the overall mean, $G_{i}$ is the effect of sheep difference $(i=1-4), P_{j}$ is effect of period $(j=1-4), T_{k}$ is the fixed effect of treatment $(k=1-4)$, and $e_{i j k l}$ is the residual effect. Differences among means were tested using Duncan's multiple range tests. Statistical significance were considered if $\mathrm{P}<0.05$.

\section{Results}

\subsection{Ruminal fermentation parameters and microbial population}

No difference was observed in rumen $\mathrm{pH}$ among treatments (Table 3). Ammonia nitrogen concentration decreased in the three EO-added treatments $(\mathrm{P}<0.01)$. Total VFA concentration decreased $(\mathrm{P}<0.05)$ in EOC-and HEOAC-added treatments. Acetate proportion was not influenced by addition of EOC or EOAC, whereas propionate proportion increased (P<0.05) in the three EO-added treatments, resulting in a reduction of the acetate-to-propionate ratio. Population of protozoa, $F$. succinogenes, and $B$. fibrisolvens decreased $(\mathrm{P}<0.05)$ in the rumen of the three EO-added sheep, with a more pronounced decrease observed in the HEOAC and LEOAC groups. Fungi and $R$. flavefaciens were not influenced by addition of EOC or 
Table 3

Effect of additives on fermentation parameters and microbial population in the rumen of Hu sheep.

\begin{tabular}{|c|c|c|c|c|c|c|}
\hline & \multicolumn{4}{|l|}{ Diet $^{\mathrm{a}}$} & \multirow[t]{2}{*}{ SEM } & \multirow[t]{2}{*}{$P$} \\
\hline & Control & EOC & LEOAC & HEOAC & & \\
\hline \multicolumn{7}{|l|}{ Fermentation parameters } \\
\hline $\mathrm{pH}$ & 6.76 & 6.73 & 6.88 & 6.68 & 0.153 & 0.095 \\
\hline Ammonia nitrogen, mg/dL & $14.8^{\mathrm{a}}$ & $12.0^{c}$ & $13.1^{\mathrm{bc}}$ & $13.5^{\mathrm{b}}$ & 0.48 & 0.004 \\
\hline Total volatile fatty acid, mM & $63.1^{\mathrm{a}}$ & $60.7^{\mathrm{b}}$ & $64.2^{\mathrm{a}}$ & $58.9^{\mathrm{b}}$ & 1.12 & 0.002 \\
\hline Acetate, $\mathrm{mol} / 100 \mathrm{~mol}$ & 76.1 & 74.0 & 72.7 & 73.2 & 1.83 & 0.116 \\
\hline Propionate, $\mathrm{mol} / 100 \mathrm{~mol}$ & $17.7^{\mathrm{b}}$ & $20.1^{\mathrm{a}}$ & $19.5^{\mathrm{ab}}$ & $19.5^{\mathrm{ab}}$ & 0.63 & 0.016 \\
\hline Butyrate, $\mathrm{mol} / 100 \mathrm{~mol}$ & $8.2^{\mathrm{a}}$ & $7.4^{\mathrm{b}}$ & $7.5^{\mathrm{b}}$ & $8.2^{\mathrm{a}}$ & 0.22 & 0.026 \\
\hline Acetate:propionate & $4.29^{\mathrm{a}}$ & $3.68^{b}$ & $3.75^{b}$ & $3.75^{b}$ & 0.124 & 0.018 \\
\hline \multicolumn{7}{|c|}{ Microbial population, \% of the total bacteria } \\
\hline Protozoa & $3.50^{\mathrm{a}}$ & $1.51^{\mathrm{b}}$ & $0.30^{c}$ & $0.70^{c}$ & 0.451 & $<0.001$ \\
\hline Fungi & 0.28 & 0.32 & 0.30 & 0.28 & 0.021 & 0.612 \\
\hline F. succinogenes & $0.46^{\mathrm{a}}$ & $0.33^{\mathrm{b}}$ & $0.16^{\mathrm{c}}$ & $0.11^{\mathrm{c}}$ & 0.041 & $<0.001$ \\
\hline B. fibrisolvens, $\times 10^{-2}$ & $1.10^{\mathrm{a}}$ & $1.01^{\mathrm{a}}$ & $0.18^{\mathrm{b}}$ & $0.20^{\mathrm{b}}$ & 0.232 & $<0.001$ \\
\hline R. flavefaciens, $\times 10^{-2}$ & 1.93 & 2.07 & 1.99 & 1.60 & 0.151 & 0.123 \\
\hline Methanogen & $0.52^{\mathrm{a}}$ & $0.57^{a}$ & $0.42^{\mathrm{b}}$ & $0.45^{\mathrm{b}}$ & 0.032 & 0.002 \\
\hline
\end{tabular}

$(\mathrm{a}, \mathrm{b}, \mathrm{c})$ Means with different superscripts in the same row differ $(\mathrm{P}<0.05)$.

a Control, basal diet added with $25 \mathrm{~g}$ /day monosodium fumarate; EOC, diet C plus $1 \mathrm{~g} /$ day of essential oil combination (mixture of equal ratio of oil from clove, oregano, cinnamon and lemon); and LEOAC or HEOAC, diet C plus 0.5 or $1.0 \mathrm{~g} /$ day essential oil active compound combination (mixture of equal ratio of eugenol, carvacrol, citral and cinnamaldehyde).

EOAC. Methanogen population decreased in the rumen of LEOAC- and HEOAC-added sheep (P<0.05). Similar effects on ruminal fermentation parameters were observed in the EOC and HEOAC treatments (their addition level were $1 \mathrm{~g} /$ day), although HEOAC showed more detrimental effects on the populations of protozoa, methanogens, $F$. succinogenes, and $B$. fibrisolvens.

\subsection{Dry matter and crude protein digestibility}

Results on DM and CP digestibility at different gut sites are presented in Table 4. The DM intake of the three EO-treated sheep had no statistical difference with that of the control. Concentrate DM intake was not altered in all the treatments,

Table 4

Effect of combined additives on flux and digestibility of dry matter and crude protein at different sites of digestive tracts in sheep.

\begin{tabular}{|c|c|c|c|c|c|c|}
\hline \multirow[t]{2}{*}{ Index } & \multicolumn{4}{|l|}{$\operatorname{Diet}^{\mathrm{a}}$} & \multirow[t]{2}{*}{ SEM } & \multirow[t]{2}{*}{$P$} \\
\hline & Control & EOC & LEOAC & HEOAC & & \\
\hline \multicolumn{7}{|l|}{ Dry matter } \\
\hline Intake, g/day & $770^{\mathrm{ab}}$ & $789^{a}$ & $778^{\mathrm{ab}}$ & $762^{\mathrm{b}}$ & 10.5 & 0.035 \\
\hline Concentrate mixture & 346 & 345 & 337 & 339 & 4.6 & 0.712 \\
\hline Chinese wild rye & $424^{\mathrm{b}}$ & $444^{\mathrm{a}}$ & $441^{\mathrm{a}}$ & $422^{\mathrm{b}}$ & 5.2 & 0.003 \\
\hline Duodenal flux, g/day & $442^{\mathrm{b}}$ & $470^{\mathrm{a}}$ & $453^{\mathrm{b}}$ & $456^{\mathrm{ab}}$ & 7.6 & 0.018 \\
\hline Forestomach digestibility & 0.426 & 0.405 & 0.418 & 0.401 & 0.013 & 0.513 \\
\hline Ileal flux, g/day & $275^{b}$ & $292^{\mathrm{a}}$ & $271^{\mathrm{b}}$ & $283^{\mathrm{ab}}$ & 5.1 & 0.026 \\
\hline \multicolumn{7}{|l|}{ Small intestinal digestibility } \\
\hline $\mathrm{g}$ digested/g ingested & 0.378 & 0.378 & 0.402 & 0.381 & 0.013 & 0.421 \\
\hline g digested/g duodenal flux & 0.217 & 0.225 & 0.234 & 0.228 & 0.010 & 0.367 \\
\hline Fecal output, g/day & $254^{\mathrm{a}}$ & $247^{\mathrm{b}}$ & $246^{\mathrm{b}}$ & $254^{\mathrm{a}}$ & 3.5 & 0.004 \\
\hline Total digestive tract digestibility & 0.671 & 0.687 & 0.684 & 0.666 & 0.019 & 0.715 \\
\hline \multicolumn{7}{|l|}{ Crude protein } \\
\hline Intake, g/day & 83 & 85 & 83 & 82 & 2.5 & 0.618 \\
\hline Duodenal flux, g/day & $71^{\mathrm{b}}$ & $76^{\mathrm{a}}$ & $74^{\mathrm{ab}}$ & $73^{\mathrm{ab}}$ & 2.0 & 0.026 \\
\hline Forestomach digestibility & $0.138^{\mathrm{a}}$ & $0.108^{\mathrm{b}}$ & $0.115^{\mathrm{b}}$ & $0.102^{\mathrm{b}}$ & 0.008 & 0.004 \\
\hline Ileal flux, g/day & 25 & 26 & 25 & 25 & 1.12 & 0.745 \\
\hline \multicolumn{7}{|l|}{ Small intestinal digestibility } \\
\hline $\mathrm{g}$ digested $/ \mathrm{g}$ ingested & 0.556 & 0.589 & 0.588 & 0.589 & 0.021 & 0.512 \\
\hline g digested/g duodenal flux & 0.646 & 0.660 & 0.664 & 0.655 & 0.019 & 0.381 \\
\hline Fecal output, g/day & 23 & 25 & 24 & 25 & 1.1 & 0.215 \\
\hline Total digestive tract digestibility & 0.720 & 0.710 & 0.707 & 0.695 & 0.022 & 0.175 \\
\hline
\end{tabular}

(a,b,c) Means with different superscripts in the same row differ $(\mathrm{P}<0.05)$.

${ }^{\text {a }} \mathrm{C}$, basal diet added with $25 \mathrm{~g}$ /day monosodium fumarate; EOC, diet C plus $1 \mathrm{~g} /$ day of essential oil combination (mixture of equal ratio of oil from clove, oregano, cinnamon and lemon); and LEOAC or HEOAC, diet C plus 0.5 or $1.0 \mathrm{~g} /$ day essential oil active compound combination (mixture of equal ratio of eugenol, carvacrol, citral and cinnamaldehyde). 
Table 5

Effect of combined additives on flux and digestibility of fiber fractions at different sites of digestive tracts in sheep.

\begin{tabular}{|c|c|c|c|c|c|c|}
\hline \multirow[t]{2}{*}{ Index } & \multicolumn{4}{|l|}{ Diet $^{\mathrm{a}}$} & \multirow[t]{2}{*}{ SEM } & \multirow[t]{2}{*}{$P$} \\
\hline & Control & $\mathrm{EOC}$ & LEOAC & HEOAC & & \\
\hline \multicolumn{7}{|l|}{ Neutral detergent fiber } \\
\hline Intake, g/day & $325^{\mathrm{ab}}$ & $333^{a}$ & $328^{\mathrm{ab}}$ & $321^{\mathrm{b}}$ & 4.7 & 0.024 \\
\hline Duodenal flux, g/day & $156^{\mathrm{b}}$ & $168^{\mathrm{a}}$ & $162^{\mathrm{b}}$ & $161^{\mathrm{b}}$ & 2.8 & 0.014 \\
\hline Forestomach digestibility & 0.519 & 0.495 & 0.506 & 0.498 & 0.019 & 0.642 \\
\hline Ileal flux, g/day & $134^{\mathrm{bc}}$ & $143^{\mathrm{a}}$ & $132^{\mathrm{c}}$ & $138^{\mathrm{ab}}$ & 2.4 & 0.004 \\
\hline \multicolumn{7}{|l|}{ Small intestinal digestibility } \\
\hline g digested/g ingested & $0.067^{c}$ & $0.076^{\mathrm{b}}$ & $0.091^{\mathrm{a}}$ & $0.072^{\mathrm{bc}}$ & 0.005 & 0.008 \\
\hline g digested/g duodenal flux & $0.140^{\mathrm{b}}$ & $0.151^{\mathrm{b}}$ & $0.183^{\mathrm{a}}$ & $0.144^{\mathrm{b}}$ & 0.008 & 0.013 \\
\hline Fecal output, g/day & 127 & 124 & 122 & 127 & 2.26 & 0.761 \\
\hline Total digestive tract digestibility & 0.610 & 0.627 & 0.626 & 0.605 & 0.015 & 0.531 \\
\hline \multicolumn{7}{|l|}{ Acid detergent fiber } \\
\hline Intake, g/day & $191^{\mathrm{ab}}$ & $196^{\mathrm{a}}$ & $193^{\mathrm{ab}}$ & $189^{\mathrm{b}}$ & 3.3 & 0.034 \\
\hline Duodenal flux, g/day & $116^{\mathrm{b}}$ & $123^{\mathrm{a}}$ & $119^{\mathrm{ab}}$ & $120^{\mathrm{ab}}$ & 2.2 & 0.026 \\
\hline Forestomach digestibility & $0.392^{\mathrm{a}}$ & $0.369^{\mathrm{b}}$ & $0.383^{\mathrm{ab}}$ & $0.365^{\mathrm{b}}$ & 0.011 & 0.004 \\
\hline Ileal flux, g/day & $96^{\mathrm{b}}$ & $102^{\mathrm{a}}$ & $95^{\mathrm{b}}$ & $99^{\mathrm{ab}}$ & 2.4 & 0.034 \\
\hline \multicolumn{7}{|l|}{ Small intestinal digestibility } \\
\hline g digested/g ingested & $0.105^{\mathrm{b}}$ & $0.109^{\mathrm{b}}$ & $0.127^{\mathrm{a}}$ & $0.112^{\mathrm{b}}$ & 0.006 & 0.004 \\
\hline $\mathrm{g}$ digested/g duodenal flux & $0.173^{\mathrm{b}}$ & $0.173^{\mathrm{b}}$ & $0.206^{\mathrm{a}}$ & $0.177^{b}$ & 0.008 & 0.007 \\
\hline Fecal output, g/day & 94 & 96 & 96 & 95 & 2.3 & 0.546 \\
\hline Total digestive tract digestibility & 0.507 & 0.510 & 0.505 & 0.500 & 0.016 & 0.687 \\
\hline
\end{tabular}

(a,b,c) Means with different superscripts in the same row differ $(\mathrm{P}<0.05)$.

a Control, basal diet added with $25 \mathrm{~g}$ /day monosodium fumarate; EOC, diet C plus $1 \mathrm{~g} /$ day of essential oil combination (mixture of equal ratio of oil from clove, oregano, cinnamon and lemon); and LEOAC or HEOAC, diet C plus 0.5 or $1.0 \mathrm{~g} /$ day essential oil active compound combination (mixture of equal ratio of eugenol, carvacrol, citral and cinnamaldehyde).

whereas roughage DM intake was increased by EOC and LEOAC compared with the control $(\mathrm{P}<0.05)$. No differences were observed among all treatments in terms of DM forestomach digestibility. Fecal output was higher in EOC and LEOAC groups, but no difference was seen in DM total digestive tract digestibility in all groups. Combined additives had no influence on $\mathrm{CP}$ intake. Forestomach digestibility of $\mathrm{CP}$ decreased $(\mathrm{P}<0.05)$ in all of the three EO-added treatments, but ileal flux and fecal output, as well as small intestinal and total gut apparent digestibility of $\mathrm{CP}$, were not influenced by the additives. Except for the DM and forage intake in EOC treatment, which was higher than those in the HEOAC treatment, no difference was observed in digestibility of DM and CP at every gut site between the two treatments.

\subsection{Fiber digestibility}

No difference existed in ADFom and NDFom intake of the three EO-added treatments compared with control (Table 5), but those of EOC and LEOAC tended to be higher than the control. NDFom and ADFom forestomach digestibility values in the control group were higher compared with the three EO-added treatments. These two parameters were lower in EOC- and HEOAC-added sheep. ADFom forestomach digestibility in EOC and HEOAC treatments were especially lower than that of the control $(\mathrm{P}<0.05)$. NDFom and ADFom digestibility values in the small intestines of the control group were lower compared with the three EO-added sheep, and the NDFom and ADFom intestinal digestibility values in LEOAC-added sheep were the highest in all treatments, and were especially higher compared with the control $(\mathrm{P}<0.05)$. No differences were seen in NDFom and ADFom fecal output and total digestive tract digestibility among all treatments.

\section{Discussion}

The potential uses of EO as a rumen fermentation modifier have been reported (Molero et al., 2004). The positive effects of EO, including increased propionate and decreased ammonia nitrogen and methane production without reducing total VFA production, have been observed in many in vitro experiments (Busquet et al., 2006; Calsamiglia et al., 2007). In the current study, the decrease of the acetate-to-propionate ratio and ammonia nitrogen concentration were also observed in the rumen of the three EOC- or EOAC-added sheep, despite the addition of fumarate in the control sheep. These results are consistent with that of Baraka and Abdl-Rahman (2012), who reported that combined addition of eugenol and fumarate is efficient in reducing methanogenesis and ammonia nitrogen. Fumarate, which serves as a key intermediate in ruminal microbial metabolism, can also decrease the acetate-to-propionate ratio (Ungerfeld et al., 2007). EO activity is mainly related to their strong antimicrobial activity against protozoa and Gram-positive rumen bacteria, such as hyper-ammonia- and acetateproducing bacteria (Chao et al., 2000; Patra and Yu, 2012). Therefore, EO and fumarate may have separate effects on ruminal fermentation, and such effects would be enhanced when these components are added together. Propionate increase after 
addition of EO is related to Gram-negative bacteria; usually, propionate-producer species are more resistant to EO (Holley and Patel, 2005). Inhibition of acetate-producing bacteria increases competitiveness.

Addition of EO or EOC with fumarate decreases methane production compared with the lone addition of EO, indicating that the addition of EO with fumarate would achieve a synergistic effect (Lin et al., 2012). Many in vivo studies on fumarate have been conducted. Most of them reported that fumarate does not negatively affect feed intake and nutrient digestion (Beauchemin and McGinn, 2006; Wood et al., 2009). Therefore, the current study is mainly concerned on the effects of EO or EOAC on in vivo fermentation and digestion. Protozoan population decreased with the addition of either EOC or EOAC, and methanogen population was reduced in the two EOAC-added treatments in the present study, confirming the conclusion of other studies (McIntosh et al., 2003; Ohene-Adjei et al., 2008). Methane production was not measured in the current in vivo study, but the decrease of the acetate-to-propionate ratio, as well as of protozoa and methanogens, indicates that methane may be inhibited in in vitro studies. Under the same addition level (1 g/day), EOAC showed higher inhibiting effects on protozoa and methanogens compared with EOC, which is not consistent with results in two previous in vitro studies (Lin et al., 2012, 2013), which showed EOC as more effective in protozoa and methanogen inhibition. The two fibrolytic bacteria, F. succinogenes and B. fibrisolvens, were somewhat inhibited in EOC- or EOAC-added treatment, but fungi and $R$. flavefaciens were not influenced. This observation is not consistent with previous in vitro studies (Lin et al., 2012), whereby fungi and $R$. flavefaciens populations were sharply inhibited by either EOC or EOAC. The results of the present study imply that the sensitivity of ruminal microbes to EO is different in in vitro and in vivo conditions, which explains the differences in effects. Additional dose of EO, density of ruminal microbes, amount of substrate, and flux rate of ruminal digesta are factors that induce these differences. Fungi, which is the most important fiber digestion-related microbe in rumen, was not influenced. Thus, ruminal fiber degradation is not greatly reduced by EOC or EOAC as in in vitro condition, as evidenced by the reduction of NDFom ruminal digestibility that did not achieve statistical significance (Table 5).

Many in vivo studies have been conducted to investigate the effect of EO on feed intake and ruminal and nutrient apparent digestibility, but results are inconsistent. Cardozo et al. (2006) reported that the combination of cinnamaldehyde (180 mg/day) and eugenol (90 mg/day) reduces total DM and water intake in beef cattle. Reduction in DM intake has also been observed in dairy cattle supplemented with high doses of cinnamaldehyde (500 mg/day; Busquet et al., 2003), which may be attributed to palatability problems. Kung et al. (2008), however, showed that addition of a blend of EO with a dose of $1.2 \mathrm{~g} / \mathrm{cow}$ per day to dairy cow feed increases DM intake and 3.5\% fat-corrected milk production. Tager and Krause (2011) found that DM intake and milk production are not influenced even though a very high dose of EO ( $10 \mathrm{~g} / \mathrm{day})$ is provided to dairy cow. In the present study, EOC and EOAC were encapsulated before being added into the concentrate mixture; thus, the additions had no influence on DM intake (Table 4). The results of the present study show encapsulation as an effective method to solve palatability problems caused by EO.

The rumen is the main site for digesting feed DM and fiber. Therefore, ruminal DM and fiber digestibility are important indices in evaluating the effects of EO on ruminant feed digestibility (Busquet et al., 2006; Lin et al., 2009). Neither EOC nor EOAC had influence on DM forestomach digestibility (Table 4), whereas NDFom $(P>0.05)$ and ADFom ( $<<0.05)$ forestomach digestibility decreased with high levels ( $1 \mathrm{~g} /$ day) of EOC and EOAC (Table 5$)$. This result corresponds to the decreased total VFA production in EOC- and HEOAC-added treatments (Table 3), indicating that high levels of EOC or EOAC can induce negative influence on fiber ruminal digestibility. These findings are consistent with the results of Tager and Krause (2011), which showed that high levels of EO negatively affect ruminal fiber degradation. A minor negative effect on fiber digestion would be due to the inhibition of total ruminal bacteria; although total bacteria was not quantified in the present study, a similar conclusion was found in other in vivo studies (Santos et al., 2010; Soltan et al., 2009; Patra and Yu, 2012). Addition of EO can increase feed protein flow into the intestine and improve feed protein utilization efficiency (Newbold et al., 2004; Hristov et al., 2008). The protein forestomach digestibility was decreased by EOC and EOAC (Table 4), consistent with the decrease of ruminal ammonia nitrogen concentration and increase of duodenal CP flux. This result suggests that ruminal bypass protein was increased by the addition of EOC and EOAC, which is a beneficial effect of EO (Newbold et al., 2004 ; Molero et al., 2004).

Most of the studies on EO are mainly concerned on ruminal fermentation or apparent nutrient digestibility (Chaves et al., 2008; Tager and Krause, 2011), but information on the impacts of EO on nutrient intestinal digestibility in ruminants is limited. Our results show that DM and CP digestibility in the intestines are not influenced by addition of EO, whereas NDFom and ADFom digestibility in the intestines are increased by the addition of EO. To the best of our knowledge, ours is the first report on the influence of EO on nutrient intestinal digestibility in ruminants. The reason for the increased fiber digestibility in the intestines as affected by EO observed in this study remains unclear. The mode of action may be similar to modes in other monogastric animals, and the activity may be attributed to digestive enzyme secretion, as well as gastric and intestinal motility stimulated by EO, which result in increased intestinal digestive ability (Westendarp, 2005). Whole tract digestibility of DM, OM, CP, NDFom, and ADFom were not affected by addition of either EOC or EOAC, indicating that feed nutrient digestibility in sheep were not influenced, and also, that the negative effects of EO on ruminal fiber digestion would be compensated by its positive effects on fiber digestion in the intestines. Non-negative effect of EO on whole tract digestion of nutrients is consistent with the results of Santos et al. (2010), who reported that addition of $0.85 \mathrm{~g} / \mathrm{day}$ of EO complex to the cows has no influence on whole tract digestion of $\mathrm{OM}, \mathrm{CP}$, and NDFom. The addition level ( $0.5 \mathrm{or} 1 \mathrm{~g} / \mathrm{day}$ ) of EOC or EOAC for sheep in the current study is higher than that in other in vivo studies conducted on dairy cows ( 1 or $2 \mathrm{~g} / \mathrm{day}$ ) (Benchaar et al., 2006; Yang et al., 2007; Tassoul and Shaver, 2009), and growing lambs with similar body weight (0.2 g/day) (Chaves et al., 2008); in these prior works, total tract digestibility was not influenced. Tager et al. (2011) also reported that 
high levels of EO (10g/day, without encapsulation) negatively affect rumen fermentation, whereas feed intake and total tract digestibility are not influenced in dairy cow. These results indicate that ruminants can endure high levels of EO than previously thought, and this level would be much higher with encapsulated EO.

\section{Conclusion}

Addition of encapsulated EOC or EOAC at $1 \mathrm{~g} /$ day had no effects on intake compared with the non-added diet, indicating that encapsulation is an effective way to promote EO acceptance in sheep. Addition of EOC or EOAC can decrease the acetateto-propionate ratio, inhibit ruminal methanogens and protozoa, and increase the amount of $\mathrm{CP}$ flowing into the duodenum despite addition of fumarate to sheep feed. Some cellolytic bacteria were decreased by the addition of EOC or EOAC, but the fungal population was not influenced. Addition of EOC and EOAC at $1 \mathrm{~g} /$ day decreased NDFom and ADFom digestion the rumen, indicating that high levels of EO is harmful to ruminal fiber digestion. The same treatments improved NDFom and ADFom digestibility in the intestines because EOC or EOAC can compensate for the negative effects. No influence of EOC or EOAC was observed on sheep apparent digestibility of DM, CP, NDFom, and ADFom, but their influence on ruminal or intestinal digestibility of nutrients were observed. Thus, apparent digestibility is a rough index and is usually not sufficient to evaluate effects of EO on nutrient digestion of ruminant digestive tract, and therefore, measurement of ruminal or intestinal digestibility is necessary. In general, EO component combinations showed similar effects on nutrient digestibility and ruminal fermentation as their corresponding natural EO combination, and $1 \mathrm{~g} /$ day of EOC or EOAC showed no obvious negative effects on sheep nutrient digestion, although ruminal fiber digestion was influenced.

\section{Acknowledgement}

This study was supported partly by grants from China-Australia Special Fund for Science and Technology (No. 2010DFA31040) and the National Natural Science Foundation of China (No. 30972105).

\section{References}

Abdl-Rahman, M.A., Sawiress, F.A.R., Abd El-Aty, A.M., 2010. Effect of sodium lauryl sulfate-fumaric acid coupled addition on the in vitro rumen fermentation with special regard to methanogenesis. Vet. Med. Int. 2010, 858474.

AOAC., 1997. Official Methods of Analysis, 16th ed. Association of Official Analytical Chemists, Arlington, VA.

Asanuma, N., Iwamoto, M., Hino, T., 1999. Effect of the addition of fumarate on methane production by ruminal microorganisms in vitro. J. Dairy Sci. 82, 780-787.

Bakkali, F., Averbeck, S., Averbeck, D., Idaomar, M., 2008. Biological effects of essential oils - a review. Food Chem. Toxicol. 46, 446-475.

Baraka, T.A.M., Abdl-Rahman, M.A., 2012. In vitro evaluation of sheep rumen fermentation pattern after adding different levels of eugenol - fumaric acid combinations. Vet. World 5, 110-117.

Beauchemin, K.A., McGinn, S.M., 2006. Methane emissions from beef cattle: effects of fumaric acid, essential oil, and canola oil. J. Anim. Sci. 84, 1489-1496.

Benchaar, C., Calsamiglia, S., Chaves, A.V., Fraser, G.R., Colombatto, D., McAllister, T.A., Beauchemin, K.A., 2008. A review of plant-derived essential oils in ruminant nutrition and production. Anim. Feed Sci. Technol. 145, 209-228.

Benchaar, C., Petit, H.V., Berthiaume, R., Whyte, T.D., Chouinard, P.Y., 2006. Effects of addition of essential oils and monensin premix on digestion, ruminal fermentation, milk production, and milk composition in dairy cows. J. Dairy Sci. 89, 4352-4364.

Busquet, M., Calsamiglia, S., Ferret, A., Greathead, H., Kamel, C., 2003. Effect of garlic extract and/or cinnamaldehyde on production, composition and residues in milk of high yielding cows. ITEA 24, 756-758.

Busquet, M., Calsamiglia, S., Ferret, A., Kamel, C., 2006. Plant extracts affect in vitro rumen microbial fermentation. J. Dairy Sci. 89, $761-771$.

Cardozo, P.W., Calsamiglia, S., Ferret, A., Kamel, C., 2006. Effects of alfalfa extract, anise, capsicum, and a mixture of cinnamaldehyde and eugenol on ruminal fermentation and protein degradation in beef heifers fed a high-concentrate diet. J. Dairy Sci. 84, 2801-2808.

Calsamiglia, S., Busquet, M., Cardozo, P.W., Castillejos, L., Ferret, A., 2007. Invited review: essential oils as modifiers of rumen microbial fermentation. J. Dairy Sci. 90, 2580-2595.

Castillejos, L., Calsamiglia, S., Ferret, A., 2006. Effect of essential oil active compounds on rumen microbial fermentation and nutrient flow in in vitro systems. J. Dairy Sci. 89, 2649-2658.

Chan, L.W., Lim, L.T., Heng, P.W., 2000. Microencapsulation of oils using sodium alginate. J. Microencapsulation 17, 757-766.

Chao, S.C., Young, D.G., Oberg, C.J., 2000. Screening for inhibitory activity of essential oils on selected bacteria, fungi and viruses. J. Essent. Oil Res. 12, 639-649.

Chaves, A.V., Stanford, K., Dugan, M.E.R., Gibson, L.L., McAllister, T.A., Van Herk, F., Benchaar, C., 2008. Effects of cinnamaldehyde, garlic and juniper berry essential oils on rumen fermentation, blood metabolites, growth performance, and carcass characteristics of growing lambs. Livest. Sci. 117, $215-224$.

Denman, S.E., McSweeney, C.S., 2006. Development of a real-time PCR assay for monitoring anaerobic fungal and cellulolytic bacterial populations within the rumen. FEMS Microbiol. Ecol. 58, 572-582.

Denman, S.E., Tomkins, N.W., McSweeney, C.S., 2007. Quantitation and diversity analysis of ruminal methanogenic populations in response to the antimethanogenic compound bromochloromethane. FEMS Microbiol. Ecol. 62, 313-322.

Holley, R.A., Patel, D., 2005. Improvement in shelf-life and safety of perishable foods by plant essential oils and smoke antimicrobials. Food Microbiol. 22, 273-292.

Hristov, A.N., Ropp, J.K., Zaman, S., Melgar, A., 2008. Effects of essential oils on in vitro ruminal fermentation and ammonia release. Anim. Feed Sci. Technol. $144,55-64$.

Hu, W.L., Liu, J.X., Ye, J.A., Wu, Y.M., Guo, Y.Q., 2005. Effect of tea saponin on rumen fermentation in vitro. Anim. Feed Sci. Technol. 120, 333-339.

Kung, L.J., Williams, P., Schmidt, R.J., Hu, W., 2008. A blend of essential plant oils used as an additive to alter silage fermentation or used as a feed additive for lactating dairy cows. J. Dairy Sci. 91, 4793-4800.

Lin, B., Tan, Z., Xiao, G., Wang, M., Cong, Z., Wang, S., Tang, S., Zhou, C., Sun, Z., Wang, W., 2009. Evaluation of compositional and nutritional equivalence of genetically modified rice to conventional rice using in situ and in vitro techniques. J. Sci. Food Agric. 89, $1490-1497$.

Lin, B., Lu, Y., Wang, J.H., Liang, Q., Liu, J.X., 2012. Effects of combined essential oils along with fumarate on rumen fermentation and methane production in vitro. J. Anim. Feed. Sci. 21, 198-210.

Lin, B., Wang, J.H., Lu, Y., Liang, Q., Liu, J.X., 2013. In vitro rumen fermentation and methane production are influenced by active components of essential oils combined with fumarate. J. Anim. Physiol. Anim. Nutr. 97, 1-9. 
Macheboeuf, D., Morgavi, D.P., Papon, Y., Mousset, J.L., Arturo-Schaan, M., 2008. Dose-response effects of essential oils on in vitro fermentation activity of the rumen microbial population. Anim. Feed Sci. Technol. 145, 335-350.

McIntosh, F.M., Williams, P., Losa, R., Wallace, R.J., Beever, D.A., Newbold, C.J., 2003. Effects of essential oils on ruminal microorganisms and their protein metabolism. Appl. Environ. Microbiol. 69, 5011-5014.

Molero, R., Ibars, M., Calsamiglia, S., Ferret, A., Losa, R., 2004. Effects of a specific blend of essential oil compounds on dry matter and crude protein degradability in heifers fed diets with different forage to concentrate ratios. Anim. Feed Sci. Technol. 114, 91-104.

Newbold, C.J., McIntosh, F.M., Williams, P., Losa, R., Wallace, R.J., 2004. Effects of a specific blend of essential oil compounds on rumen fermentation. Anim. Feed Sci. Technol. 114, 105-112.

Ohene-Adjei, S., Chaves, A., McAllister, T., Benchaar, C., Teather, R., Forster, R., 2008. Evidence of increased diversity of methanogenic archaea with plant extract supplementation. Microb. Ecol. 56, 234-242.

Patra, A.K., Yu, Z., 2012. Effects of essential oils on methane production, fermentation, abundance and diversity of rumen microbial populations. Appl. Environ. Microbiol. 78, 4271-4280.

Santos, M.B., Robinson, P.H., Williams, P., Losa, R., 2010. Effects of addition of an essential oil complex to the diet of lactating dairy cows on whole tract digestion of nutrients and productive performance. Anim. Feed Sci. Technol. 157, 64-71.

SAS Institute, 2005. SAS Online Doc version 9.1.3. SAS Inst., Inc., Cary, NC.

Searle, L.P., 1984. The berthelot or indophenol reaction and its use in the analytical chemistry of nitrogen: a review. Analyst 109, 549-568.

Soltan, M.A.E., Shewita, R.S., Al-Sultan, S.I., 2009. Influence of essential oils supplementation on digestion, rumen fermentation, rumen microbial populations and productive performance of dairy cows. Asian-Aust. J. Anim. Sci. 3, 1-12.

Tager, L.R., Krause, K.M., 2011. Effects of essential oils on rumen fermentation, milk production, and feeding behavior in lactating dairy cows. J. Dairy Sci. $94,2455-2464$.

Tan, Z.L., Lu, D.X., Hu, M., Niu, W.Y., Han, C.Y., Ren, X.P., Na, R., Lin, S.L., 2001. Effects of dietary nitrogen sources on fiber digestion and ruminal fluid characteristics in sheep fed wheat straw. Asian-Aust. J. Anim. Sci. 14, 1374-1382.

Tassoul, M.D., Shaver, R.D., 2009. Effect of a mixture of supplemental dietary plant essential oils on performance of periparturient and early lactation dairy cows. J. Dairy Sci. 92, 1734-1740.

Ungerfeld, E.M., Kohn, R.A., Wallace, R.J., Newbold, C.J., 2007. A meta-analysis of fumarate effects on methane production in ruminal batch cultures. J. Anim. Sci. 85, 2556-2563.

Van Soest, P.J., Bobertson, J.B., Lewis, B.A., 1991. Methods of dietary fiber, NDF and non-starch polysaccharides in relation to animal nutrition. J. Dairy Sci. $74,3583-3597$

Wallace, R.J., 2004. Antimicrobial properties of plant secondary metabolites. Proc. Nutr. Soc. 63, 621-629.

Wang, H., Dai, Q., Li, Q., Yang, J., Zhong, X., Huang, Y., Zhang, A., Yan, Z., 2009. Preparation of porous carbon spheres from porous starch. Solid State Ionics $180,1429-1432$

Westendarp, H., 2005. Essential oils for the nutrition of poultry, swine and ruminants. Dtsch. Tierarztl. Wochenschr. 112, 375-380 (in German with English summary).

Wood, T.A., Wallace, R.J., Rowe, A., Price, J., Yáñez-Ruiz, D.R., Murray, P., Newbold, C.J., 2009. Encapsulated fumaric acid as a feed ingredient to decrease ruminal methane emissions. Anim. Feed Sci. Technol. 152, 62-71.

Yang, W.Z., Benchaar, C., Ametaj, B.N., Chaves, A.V., He, M.L., McAllister, T.A., 2007. Effects of garlic and juniper berry essential oils on ruminal fermentation and on the site and extent of digestion in lactating cows. J. Dairy Sci. 90, 5671-5681.

Zhang, C.M., Guo, Y.Q., Yuan, Z.P., Wu, Y.M., Wang, J.K., Liu, J.X., Zhu, W.Y., 2008. Effect of octadeca carbon fatty acids on microbial fermentation, methanogenesis and microbial flora in vitro. Anim. Feed Sci. Technol. 146, 259-269. 